\title{
Family planning knowledge and current use of contraception among the Mru indigenous women in Bangladesh: a multivariate analysis
}

This article was published in the following Dove Press journal:

Open Access Journal of Contraception

28 February 2012

Number of times this article has been viewed

\author{
M Rakibul Islam' \\ Gunnar Thorvaldsen² \\ 'Bangladesh Agricultural University, \\ Bangladesh; ${ }^{2}$ Norwegian Historical \\ Data Centre, University of Tromsø, \\ Norway
}

Correspondence: M Rakibul Islam Department of Rural Sociology, Bangladesh Agricultural University, Mymensingh-2202, Bangladesh Tel $+88017 \quad$ I222I677

Fax +88 091 61510

Email rakib.no@live.no
Background: This article aims to understand the family planning (FP) knowledge and current use of contraception and its predictors among women of the Mru people - the most underprivileged indigenous community in Bangladesh.

Methods: In this study, 374 currently married Mru women were interviewed and selected purposively from three upazilas (administrative subdistricts) of the Bandarban area, where most of the Mru people live. The association between the variables was assessed in bivariate analysis using the Chi-square test and binary logistic regression models were employed to explore the predictors of FP knowledge and current use of contraception among the Mru women.

Results: Only about $40 \%$ of respondents had ever heard FP messages or about FP methods - two-fifths of the national figure (99.9\%). The current use of contraception was much lower (25.1\%) among the Mru people than at the national level (55.8\%). Among both modern and traditional methods, the contraceptive pill ranked first. About two-thirds $(66.0 \%)$ of married women used this method - more than two times than the national figure $(28.5 \%)$. On the other hand, the prevalence of male methods was comparatively lower than at the national level. Logistic regression models revealed that place of residence, religion, age, school attendance, husband's school attendance, service provided in the community, distance to the service center, and exposure to mass media had significant effects on knowledge of FP and on use of contraception.

Conclusion: Education for mothers and vernacular language-based doorstep FP programs with special emphasis on awareness are suggested for the community.

Keywords: family planning, contraceptive use, the Mru, logistic regression, Bangladesh

\section{Introduction}

In recent years, knowledge of family planning (FP) and contraceptive use have accelerated in Bangladesh and are playing a remarkable role in controlling fertility, particularly in reaching the replacement level of fertility. In this regard, both government and nongovernmental organizations (NGOs) have been employing various strategies. Many researchers believe this is an impressive achievement within Bangladesh, a Muslim country where different familial, socioeconomic, cultural, and religious taboos still prevail. ${ }^{1}$ Almost all married women in Bangladesh (99.9\%) have heard of at least one FP method. The use of contraception among married women has increased from $7.7 \%$ in 1975 to $55.8 \%$ in 2007 . Although the overall knowledge of contraceptive methods is high in Bangladesh, the prevalence of use of these methods is not high. ${ }^{2-4}$

Contraceptive use declined from 58.1\% in 2004 to $55.8 \%$ in 2007, but this change has taken place mostly in the use of traditional methods. ${ }^{2}$ Modern methods are now 
more used than traditional methods. Traditional methods (namely, periodic abstinence and withdrawal) are difficult to use consistently. They require strong spousal communication, discipline, and understanding, and have a high rate of failure. ${ }^{5}$ Men do not have sufficient knowledge about traditional methods in Bangladesh. ${ }^{6}$ Clinical methods used by men are significantly rarer than non-clinical methods. ${ }^{7}$ Condom use is disparaged for aesthetic reasons and because it is a frustrating method - condoms are embarrassing to obtain, difficult to store, clumsy to use, and nuisance to dispose of. ${ }^{5}$

In Bangladesh, oral contraception is popular and is gradually increasing its share in the current methods mix. ${ }^{5}$ Nevertheless, studies have revealed that discontinuation of the oral pill is common among women in Bangladesh, with side effects considered a possible factor for this., ${ }^{8,9}$

Although fertility rates in Bangladesh have declined and the prevalence of contraception use has increased through extensive FP programs, this development has spread disproportionately among different indigenous, non-indigenous, and cultural groups. The Mru indigenous community is predominantly untouched by the startling development of FP and use of contraception in Bangladesh. Systematic research on FP and contraception has not been conducted in this community before. Thus, the purpose of this paper is to understand the FP knowledge and current use of contraception and its determinants among the Mru women in Bangladesh.

\section{Ethnography of the Mru}

The Mru are the largest small indigenous group in Bangladesh and the most underprivileged. They live among hilltops, ravines, cliffs, and deep forest areas of the Bandarban district. Although the Mru now live in the southern part of the Chittagong Hill Tracts (CHT), they originally came to this region several hundred years ago from the state of Arakan in Mayanmar, owing to a blood feud with the Khumi tribe. ${ }^{10,11}$ Linguistically and culturally, the Mru categorize themselves into five distinctive groups: the Anok (meaning "West"), who live in the south of Bandarban; the Tshung ("Mountain People"), who have joined the Anok living in the southern part in the upper Sangu valley; the Domrong ("Lowlands"), who live in the north of Matamuhuri river; and the Dopreng and Rumma ("Forest People") who live in the far south and in the Arakan. ${ }^{10}$ The Mru live in 356 villages (paras), comprising 5398 households. ${ }^{12}$ In a census conducted in 1995 by the Mru Social Culture, the total population was estimated at $59,748 .{ }^{13}$ The male to female education ratio is 2.6 to 1.6. Ninety-three percent of villages are more than one mile away from a primary school. ${ }^{12}$

\section{New religion: the Crama}

Before the 1950s, the Mru people believed in animism and Buddhism. Since then, some Mru have converted to Christianity. Nowadays, the majority of the Mru people belong to a new religion: Crama. Man Ley Mru, the founder of Crama, started disseminating religious and moral messages to the Mru in the 1980s. In 1985, when he was 19 years old, he arranged a meeting of the Mru people and announced that he had created a new religion for them, since they did not have then a distinguishing religion. He also created the alphabet for the Mru language. The Reyung Khiti ("good ethics") is the central religious book of Crama. This book is comprised of messages taken mostly from Christianity, Buddhism, and Hinduism. Religious rituals are conducted by congregation members. At age twelve, a boy or a girl is sent to a prayer room (Kiyang Ghar) for religious purification, which is conducted by a priest, and is taught the rules, regulations, and messages of the religion. ${ }^{14}$

\section{Family planning and reproductive health}

In general, FP services for the Mru society are inadequate, due to the non-existence of local service centers and the need to travel long distances to get to other centers. Only a few villages have access to FP suggestions and contraceptives from centers a short distance away. ${ }^{14}$ Small-scale outreach projects have been recently started by NGOs in some areas of Lama and Thanchi but Alikadam has not yet been included. ${ }^{15}$ However, most of these projects are general health awareness programs, rather than initiatives to provide contraceptives to villagers. A recent study showed that nutrition among mothers is poor in the Mru society. After delivery, a mother is given only salted rice and she sits beside a fire from 9 to 30 days, depending upon village practice. Their visits to antenatal and postnatal care are few compared with mainstream society due to cultural issues, distance, lack of infrastructure, and low socioeconomic status. Furthermore, mothers mostly depend on traditional village healers (TVHs) and traditional midwives, rather than going to hospitals. ${ }^{15}$

\section{Methods and materials}

The Bandarban district has seven upazilas (administrative subdistricts), three of which were selected for this study: Alikadam, Lama, and Thanchi. There were four reasons why these were selected as study areas and these have been discussed elsewhere. ${ }^{15}$ A total of 374 currently married Mru women, comprising 133 from Alikadam, 170 from Lama, and 71 from Thanchi, who had at least one child aged 5 years or 
younger were included in the study. Women whose children had died were also selected for face-to-face interviews. Only married women were included in this study so that their situation could be compared with those of mainstream society as premarital sex is socially prohibited in Bangladesh (the Bangladesh Demographic and Health Survey also does not include unmarried women).

A questionnaire was used for the collection of primary information, which included both closed- and open-ended questions. Since the Mru have a distinct language and are unable to communicate in the Bengali language, seven bilingual female interviewers from the Mru community were recruited to conduct the interviews. The interviewers had 9 to 12 years of schooling. Three interviewers were health workers with NGOs, one had undertaken formal training as a midwife at a private medical college hospital, two were students, and the others were housewives. A pilot survey was conducted before using the questionnaire for data collection.

\section{Dependent variables}

The dependent variables used in this study were knowledge of FP and current use of contraception. FP knowledge was operationalized broadly, due to the Mru community's poor socioeconomic characteristics. Therefore, "FP knowledge" was defined in terms of any use of FP methods or of hearing any FP messages, over a woman's life prior to the survey. The contraceptive use variable considered both modern and traditional methods. Thus, the two dependent variables measured whether a respondent had ever heard of any FP method/message (yes $=1 ;$ no $=0$ ) and whether a respondent was currently using any FP method at the time of the survey $($ yes $=1$; no $=0)$.

\section{Independent variables}

The following demographic, socioeconomic, and spatial factors were considered independent variables for bivariate and multivariate analyses: place of residence, age, religion, education, and occupation; education and occupation of the respondent's husband; parity (birth order); place of service provision in the community; distance to service center; and exposure to mass media. "Distance" was defined as approximate distance, in kilometers, from the respondent's home to the nearest service center, as self-reported.

\section{Data analysis}

Data were summarized, tabulated, and analyzed using SPSS software (version 16.0; SPSS Inc., Chizago, IL). Bivariate analyses were performed based on cross tabulations using
Chi-square tests. Multivariate analyses were conducted in terms of binary logistic regression analysis. Some variables used in the bivariate analyses were excluded in the final regression models because they were concentrated in one category of independent variable.

\section{Results}

\section{Sample characteristics}

Among the survey respondents, $45.5 \%$ were from Lama and $35.6 \%$ were from Alikadam. The remaining respondents (19.0\%) were from the Thanchi subdistrict. The majority (30.2\%) of the respondents belonged to the 25-29 age group. The literacy rate was poor among the mothers. Most of the survey respondents $(96.5 \%)$ had not attended school. The Mru people belong to different religions: $57.2 \%$ identified as Buddhist, $25.1 \%$ as Crama, and $17.6 \%$ as Christian. Some people also believed in animism, although they introduced themselves as Buddhists. Almost all (98.7\%) of the Mru women regularly engaged in the cultivation of swidden (jum) and in household activities. Only about $40 \%$ of respondents had ever heard FP messages or of FP methods. Current use of contraception among the respondents was only $25.1 \%$.

\section{FP knowledge}

\section{Bivariate analysis}

Table 1 shows that the respondents' sociodemographic characteristics (places of residence and their religions, ages, education levels, occupations, places of service provision, and media exposure, as well as their husbands' education levels and occupations) had significant associations with the variable "Ever heard FP messages or of FP methods?" More than half of the respondents from Lama (51.8\%) had heard FP messages and of methods, while the corresponding figure from Thanchi was only $18.3 \%$. A positive response to the question "Ever heard of FP?" was found more frequently among respondents who belonged to the Crama religion (53.2\%), compared with those who belonged to Buddhism (43.9\%) or to Christianity (13.6\%). Positive responses were fewer among older than among younger women. About $85 \%$ of respondents who had attended school had heard of FP, while the corresponding percentage was less than half of that among those who had never attended school. All respondents in paid service had heard of FP. The results were similar regarding their husbands' education levels and occupations. The study reported that only $33.0 \%$ of women had heard of FP from upazila health complex (UHC), while the corresponding percentages for family welfare centers (FWCs) and others (satellite clinics [SCs], 
Table I Association between "Ever heard of family planning?" and demographic and socioeconomic characteristics, using Chi-square test

\begin{tabular}{|c|c|c|c|}
\hline \multirow[t]{2}{*}{ Characteristic } & \multirow[t]{2}{*}{$\mathbf{N}$} & \multicolumn{2}{|c|}{$\begin{array}{l}\text { Ever heard of FP? } \\
n(\%)\end{array}$} \\
\hline & & Yes & No \\
\hline \multicolumn{4}{|l|}{ Place of residence $(P<0.00 \mathrm{I})$} \\
\hline Alikadam & 133 & $52(39.1)$ & 81 (60.9) \\
\hline Lama & 170 & $88(51.8)$ & $82(48.2)$ \\
\hline Thanchi & 71 & $13(18.3)$ & $58(81.7)$ \\
\hline \multicolumn{4}{|l|}{ Religion $(P<0.001)$} \\
\hline Crama & 94 & $50(53.2)$ & $44(46.8)$ \\
\hline Buddhism & 214 & $94(43.9)$ & $120(56.1)$ \\
\hline Christianity & 66 & $9(13.6)$ & $57(86.4)$ \\
\hline \multicolumn{4}{|l|}{ Age in years $(P=0.026)$} \\
\hline$<25$ & 159 & $66(41.5)$ & $93(58.5)$ \\
\hline $25-35$ & 180 & $80(44.4)$ & $100(56)$ \\
\hline$>35$ & 35 & $7(20.0)$ & $28(80.0)$ \\
\hline \multicolumn{4}{|l|}{ School attendance $(P=0.002)^{*}$} \\
\hline Yes & 13 & II (84.6) & $2(15.4)$ \\
\hline No & 361 & $142(39.3)$ & $219(60.7)$ \\
\hline \multicolumn{4}{|l|}{ Occupation $(P=0.01 \mathrm{I})^{*}$} \\
\hline Agriculture and housewife & 369 & $148(40.1)$ & $221(59.9)$ \\
\hline Service & 5 & $5(100.0)$ & $0(0.0)$ \\
\hline \multicolumn{4}{|c|}{ Husband's school attendance $(P<0.00$ I $)$} \\
\hline Yes & 26 & $21(80.8)$ & $5(19.2)$ \\
\hline No & 348 & $132(37.9)$ & $216(62.1)$ \\
\hline \multicolumn{4}{|c|}{ Husband's occupation $(P=0.004)$} \\
\hline Agriculture & 355 & $139(39.2)$ & $216(60.8)$ \\
\hline Others & 19 & $14(73.7)$ & $5(26.3)$ \\
\hline \multicolumn{4}{|c|}{ Place of service provision $(P=0.002)$} \\
\hline Upazila health complex & 206 & $68(33.0)$ & $138(67.0)$ \\
\hline Family welfare center & 106 & $55(51.9)$ & $51(48.1)$ \\
\hline Others & 62 & $30(48.4)$ & $32(51.6)$ \\
\hline \multicolumn{4}{|l|}{ Distance, $\mathrm{km}(P=0.493)$} \\
\hline$<3$ & 54 & $21(38.9)$ & $33(6 I .1)$ \\
\hline $3-8$ & 78 & $30(38.5)$ & $48(61.5)$ \\
\hline $8-16$ & 136 & $52(38.2)$ & $84(6 I .8)$ \\
\hline$>16$ & 106 & $50(47.2)$ & $56(52.8)$ \\
\hline \multicolumn{4}{|c|}{ Mass media exposure $(P=0.004)$} \\
\hline Access to any media & 19 & 14 (73.7) & $5(26.3)$ \\
\hline No access to any media & 355 & 139 (39.2) & $216(60.8)$ \\
\hline
\end{tabular}

Notes: *Fisher's exact test has been used for the variable "school attendance," since the expected frequencies were less than five.

family members, and friends or neighbors) were $51.9 \%$ and $48.4 \%$, respectively. The study also found that respondents with exposure to any mass media, such as radio, television or newspapers, were more aware of FP than those who had had no exposure.

\section{Multivariate analysis}

A binary logistic regression model was employed to explore the determinants of FP knowledge among the Mru women who had had a live birth in the 5 years preceding the survey (Table 2 ).
Table 2 Logistic regression estimates of demographic and socioeconomic characteristics' effects on "Ever heard of family planning?"

\begin{tabular}{lll}
\hline Independent variable & Odds ratio & $\mathbf{( 9 5 \% ~ C l )}$ \\
\hline $\begin{array}{l}\text { Place of residence }(r=\text { Alikadam }) \\
\quad \text { Thanchi }\end{array}$ & 0.32 & \\
$\quad$ Lama & 4.88 & $0.13-0.76$ \\
Religion $(r=$ Crama $)$ & & $2.52-9.45$ \\
$\quad$ Christianity & 0.01 & $0.01-0.04$ \\
$\quad$ Buddhism & 0.36 & $0.19-0.69$ \\
Age in years $(r \leq 25)$ & & \\
25-35 & 1.82 & $1.03-3.23$ \\
$>35$ & 0.52 & $0.16-1.66$ \\
School attendance $(r=$ No) & & \\
$\quad$ Yes & 13.67 & $1.81-102.93$ \\
Distance in km $(r \leq 3)$ & & \\
3-8 & 0.23 & $0.06-0.91$ \\
$8-16$ & 0.31 & $0.08-1.15$ \\
$>16$ & 0.46 & $0.10-1.98$
\end{tabular}

Access to mass media

( $r=$ No access to any media)

Access to any media $\quad 9.62 \quad 2.28-40.55$

Constant 2.48

Abbreviations: $r$, reference category; $\mathrm{Cl}$, confidence interval.

Place of residence, religion, age, education level, distance to the service center, and access to mass media were shown to be the significant factors for FP knowledge within the Mru society. The analysis suggested that respondents from the Lama subdistrict were about five times more likely to have FP knowledge, relative to respondents from Alikadam, while respondents from Thanchi were even less likely to have heard any FP message. Respondents who belonged to the religions of Christianity and Buddhism were less likely to have FP knowledge, compared with those of the Crama religion. Respondents aged 25-35 years old were more likely to have heard FP messages, compared with respondents aged less than 25 years. The analysis also suggested that respondents who had attended school were more than thirteen times more likely to have FP knowledge, relative to those who had not. Respondents who resided more than $3 \mathrm{~km}$ away from a service center were significantly less likely to have FP knowledge, compared with those who lived less than $3 \mathrm{~km}$ away. The analysis further suggested that respondents who had access to mass media were about nine times more likely to have heard FP messages, relative to those who had no access.

\section{Current use of contraception}

Figure 1 demonstrates that the use of contraception was much lower (25.1\%) among the Mru people than at the 


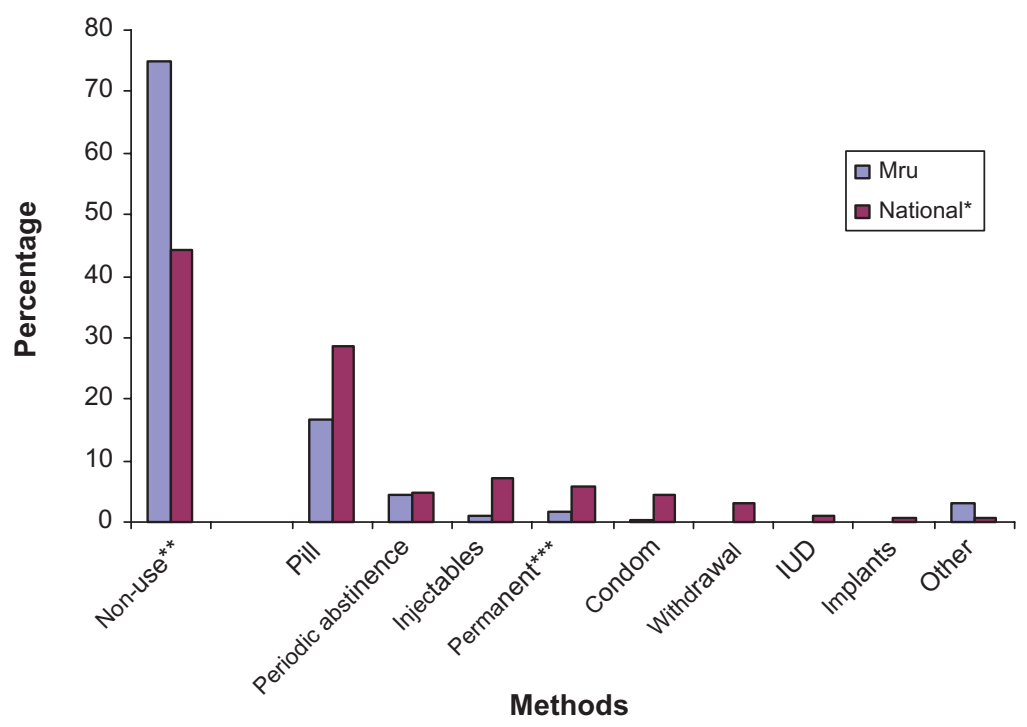

Figure I Current use of contraception by method.

Notes: *Bangladesh Demographic and Health Survey, 2007; **non-use also includes lactating mothers; ***permanent method includes both female sterilization and male sterilization.

national level (55.8\%). Among different modern and traditional methods, the contraceptive pill ranked first. About two-thirds (66.0\%) of married women were using this method, which was more than two times higher than the national figure $(28.5 \%)$. The study reported that the use of permanent methods was more than three times lower than at the national level. Male use of FP methods was also less than the national average. In particular, condom use by the Mru couples was about ten times lower than at the national level. Periodic abstinence was found to be almost identical with the national level. The practice of withdrawal, and the use of intra-uterine devices and other implants were absent among the respondents.

\section{Bivariate analysis}

Bivariate analysis (Table 3) showed that place of residence, religion, age, respondent's education and occupation, husband's education and occupation, and mass media were positively associated with current use of contraceptives among the Mru women. The study showed that less than one-third of respondents from Alikadam and Lama used contraceptives, while the corresponding value in Thanchi was only $7 \%$. Current use of contraception was found to be relatively more common among respondents who belonged to Crama and Buddhism than to Christianity. The practice of using contraception was more common among respondents in the 25-35 years age group, compared with the other age groups. Current use of contraception was more common among respondents who had attended school and were involved in paid service. The prevalence of use of contraception was also greater among respondents whose husbands had attended school and were engaged in work other than agricultural work. The study reported that $63.3 \%$ of respondents who had access to mass media used contraception, while the corresponding value was $23.1 \%$ for those who had no access to mass media.

\section{Multivariate analysis}

A binary logistic regression model was used to explore the determinants of use of contraceptive methods among the Mru women who had had a live birth in the 5 years preceding the survey (Table 4). In this multivariate regression analysis, the effect of religion was inconsistent with the bivariate analysis. In regression analysis, Christian people were shown to be using more contraception, whereas, in bivariate analysis, Crama people seemed to be using more contraception. This effect occurred when religion and education were entered in the regression model simultaneously. Further analysis of the issue revealed a significant association $(P=0.013)$ between religion and education, implying that Christians $(9.1 \%)$ were more educated than Crama followers (2.1\%) and Buddists $(2.3 \%)$. The effect of religion changed in multivariate analysis when the effect of education on religion was controlled. Thus, the religion variable was excluded from the regression model when considering the theoretical importance of education as a determinant of contraception use. 
Table 3 Association between current use of contraception and demographic and socioeconomic characteristics using Chi-square test

\begin{tabular}{|c|c|c|c|}
\hline \multirow[t]{2}{*}{ Characteristic } & \multirow[t]{2}{*}{$\mathbf{n}$} & \multicolumn{2}{|c|}{$\begin{array}{l}\text { Current use of } \\
\text { contraception } \\
\mathrm{n}(\%)\end{array}$} \\
\hline & & Yes & No \\
\hline \multicolumn{4}{|l|}{ Place of residence $(P<0.00 \mathrm{I})$} \\
\hline Alikadam & 133 & $39(29.3)$ & $94(70.7)$ \\
\hline Thanchi & 71 & $5(7.0)$ & $66(93.0)$ \\
\hline Lama & 170 & $50(29.4)$ & $120(70.6)$ \\
\hline \multicolumn{4}{|l|}{ Religion $(P=0.04 \mathrm{I})$} \\
\hline Crama & 94 & $29(30.9)$ & $65(69.1)$ \\
\hline Christianity & 66 & $9(13.6)$ & $57(86.4)$ \\
\hline Buddhism & 214 & $56(26.2)$ & $158(73.8)$ \\
\hline \multicolumn{4}{|l|}{ Age in years $(P=0.010)$} \\
\hline$<25$ & 159 & $30(18.9)$ & $129(81.1)$ \\
\hline $25-35$ & 180 & $58(32.2)$ & $122(67.8)$ \\
\hline$>35$ & 35 & $6(17.1)$ & $29(82.9)$ \\
\hline \multicolumn{4}{|l|}{ School attendance $(P<0.00 \mathrm{I}) *$} \\
\hline Yes & 13 & $10(76.9)$ & $3(23.1)$ \\
\hline No & 361 & $84(23.3)$ & $277(76.7)$ \\
\hline \multicolumn{4}{|l|}{ Occupation $(P=0.00 \mathrm{I})^{*}$} \\
\hline Agriculture and housewife & 369 & $89(24.1)$ & $280(75.9)$ \\
\hline Service & 5 & $5(100.0)$ & $0(0.0)$ \\
\hline \multicolumn{4}{|c|}{ Husband's school attendance $(P<0.00 \mathrm{I})$} \\
\hline Yes & 26 & $16(61.5)$ & $10(38.5)$ \\
\hline No & 348 & $78(22.4)$ & $210(77.6)$ \\
\hline \multicolumn{4}{|c|}{ Husband's occupation $(P<0.00 \mathrm{I})^{*}$} \\
\hline Agriculture & 355 & $81(22.8)$ & $274(77.2)$ \\
\hline Other & 19 & $13(68.4)$ & $6(31.6)$ \\
\hline \multicolumn{4}{|l|}{ Birth order $(P=0.056)$} \\
\hline 1 & 68 & II (I6.2) & $57(83.8)$ \\
\hline 2 & 85 & I8 (21.2) & $67(78.8)$ \\
\hline$\geq 3$ & 221 & $65(29.4)$ & $156(70.6)$ \\
\hline \multicolumn{4}{|c|}{ Place of service provision $(P=0.703)$} \\
\hline Upazila health complex & 206 & $49(23.8)$ & $157(76.2)$ \\
\hline Family welfare center & 106 & $27(25.5)$ & $79(74.5)$ \\
\hline Others & 62 & $18(29.0)$ & $44(7 \mid .0)$ \\
\hline \multicolumn{4}{|l|}{ Distance in $\mathrm{km}(P=0.409)$} \\
\hline$<3$ & 54 & $12(22.2)$ & $42(77.8)$ \\
\hline $3-8$ & 78 & $24(30.8)$ & $54(69.2)$ \\
\hline $8-16$ & 136 & $29(21.3)$ & $107(78.7)$ \\
\hline$>16$ & 106 & $29(27.4)$ & $77(72.6)$ \\
\hline \multicolumn{4}{|c|}{ Mass media exposure $(P<0.00 \mathrm{I})^{*}$} \\
\hline Access to any media & 19 & $12(63.3)$ & 7 (36.8) \\
\hline No access to any media & 355 & $82(23.1)$ & $273(76.9)$ \\
\hline
\end{tabular}

Notes: *Fisher's exact test has been used for school attendance, occupation, husband's occupation, and mass media exposure.

The logistic regression model suggested that place of residence, education level, husband's education level, distance to service center, and access to mass media were significant predictors of contraception use in the Mru society. Further analysis found that respondents from Lama were about eight times more likely to use contraception than those in Alikadam,
Table 4 Logistic regression estimates of demographic and socioeconomic characteristics' effects on current use of contraception

\begin{tabular}{|c|c|c|}
\hline Independent variable & Odds ratio & $(95 \% \mathrm{Cl})$ \\
\hline \multicolumn{3}{|c|}{ Place of residence $(r=$ Alikadam $)$} \\
\hline Thanchi & 1.12 & $0.52-2.41$ \\
\hline Lama & 8.41 & $2.6 I-27.13$ \\
\hline \multicolumn{3}{|l|}{ Age in years $(r \leq 25)$} \\
\hline $25-35$ & 0.83 & $0.42-1.63$ \\
\hline$>35$ & 1.52 & $0.48-4.80$ \\
\hline \multicolumn{3}{|l|}{ School attendance $(r=\mathrm{No})$} \\
\hline Yes & 4.54 & $1.37-15.11$ \\
\hline \multicolumn{3}{|c|}{ Husband's school attendance $(r=\mathrm{No})$} \\
\hline Yes & 2.61 & $0.43-15.80$ \\
\hline \multicolumn{3}{|c|}{ Service provided in the locality } \\
\hline \multicolumn{3}{|c|}{ ( $r=$ Upazila health complex $)$} \\
\hline Family welfare center & 1.27 & $0.54-2.98$ \\
\hline Others & 1.37 & $0.53-3.55$ \\
\hline \multicolumn{3}{|l|}{ Birth order $(r=1)$} \\
\hline 2 & 0.60 & $0.23-1.55$ \\
\hline$\geq 3$ & 0.44 & $0.17-1.14$ \\
\hline \multicolumn{3}{|l|}{ Distance in $\mathrm{km}(r \leq 3)$} \\
\hline $3-8$ & 0.48 & $0.18-1.30$ \\
\hline $8-16$ & 0.64 & $0.24-1.71$ \\
\hline$>16$ & 0.57 & $0.21-1.58$ \\
\hline \multicolumn{3}{|c|}{ Access to mass media } \\
\hline \multicolumn{3}{|c|}{ ( $r=$ No access to any media) } \\
\hline Access to any media & 5.90 & $1.55-22.44$ \\
\hline Constant & 0.12 & \\
\hline
\end{tabular}

Abbreviations: $r$, reference category; $\mathrm{Cl}$, confidence interval.

while respondents from Thanchi were twice as likely to use contraception. Women aged 25-35 years were less likely to use contraception, relative to those who were less than 25 years old. The analysis further suggested that respondents who had attended school, or whose husband had attended school, were more likely to use contraception, relative to those who had not attended school. Respondents who visited FWCs and other centers, such as SCs, TVHs, and village doctors, were more likely to use contraception than those who visited UHCs. Respondents who had more than one child were less likely to use contraception. It was also found that respondents who resided more than $3 \mathrm{~km}$ away from a service center were less likely to use contraception, compared with those who lived less than $3 \mathrm{~km}$ away. Exposure to mass media was found to be another significant determinant of contraception use in the Mru society - respondents who had access to radio, television or newspapers were about six times more likely to use contraception, than those who had no access.

\section{Discussion}

Since Bangladesh is one of the most densely populated countries in the world, FP is becoming increasingly important 
in the context of increasing the prevalence of contraceptive use and reducing the level of fertility. Thus, knowledge of FP methods is widespread in mainstream Bangladeshi society, where almost all married women know of at least one FP method. ${ }^{2}$ However, the involvement of the Mru women in this regard is very poor, which has not been investigated before as far as the authors are aware. This study has, therefore, attempted to address this gap by exploring the factors behind FP knowledge and use of contraceptives, surveying $374 \mathrm{Mru}$ women selected from three upazilas of the Bandarban district.

This study suggests that the Mru women's knowledge of FP is low, with $59.1 \%$ of respondents reporting never having heard of FP methods or hearing FP messages. Logistic regression analysis revealed that respondents' places of residence, their religions, ages, school attendances, distances to local service centers, and access to mass media were significant determinants of FP knowledge. All the Mru villages are far away from urban health care facilities, when compared with mainstream villages. There is no television, newspapers or mobile communication network access in these villages. Very few households have radio and what broadcasts there are only disseminate FP messages in the Bengali language, which uneducated Mru women do not understand; this might be another predictor of low level of FP knowledge. In addition, the use of contraception and its benefits are not routinely discussed by women after delivery, since standards of antenatal and postnatal care at primary health clinics are low in these communities. ${ }^{15}$

This study also revealed that the prevalence of contraceptive use among respondents was less than half of the national figure. The results might be more nuanced if information on the desire for children and other unmet needs were included; this requires further study. A recent study from India found that the use of contraception among indigenous women of Jharkhand was less than two-thirds of the national average. ${ }^{16}$ This low rate of contraceptive use might be due to the customary use of medicinal plants; again, this is an area requiring further study. A study among indigenous people in Paraguay revealed that leaves, branches, and roots of different medicinal plants have been used as contraceptives for shortterm and long-term fertility regulation. ${ }^{17}$ The contraceptive pill ranked first among methods used by the Mru women, while male methods were not prevalent (which is identical to mainstream society). ${ }^{2}$ The study found that respondents from Lama were more likely to use contraception than those from Alikadam because the area is closer to health care facilities. Additionally, the terrain of Lama is comparatively more level and more accessible than the other study areas. One of the most important predictors of current use of contraception was distance to service centers. A study among inter-ethnic communities in the CHT region found that about $85 \%$ of Bengali people had some type of institutionalized health care facilities within $5 \mathrm{~km}$ of them, while the corresponding value was only about $25 \%$ for the Mru people. ${ }^{18}$

School attendance was also a significant predictor of contraceptive use among the Mru women. A similar result was found in a recent study among indigenous people in Bangladesh, where contraception use was higher among educated Garo women when compared with uneducated women. ${ }^{19}$ Women who visited FWCs, SCs, TVHs, or village doctors were more likely to use contraceptives, which might be explained by their having greater access to these facilities. The analysis also revealed that older women were more likely to use contraceptives than those less than 25 years old, which might be due to their unwillingness to give birth to more babies. On the other hand, the fact that younger women in the Mru society usually do not go outside of their villages might be another possible factor.

\section{Conclusion}

Knowledge of FP and the use of contraception are low in the Mru community when compared with mainstream society. However, lack of FP knowledge and low use of contraceptives lead to unwanted pregnancies and to unsafe abortions that can cause maternal deaths. ${ }^{20}$ So, it is natural to suggest that doorstep health care services and SCs should be developed within the Mru villages, since they live at a distance from service centers. In addition, vernacular language-based health education for mothers and FP programs with special emphasis on awareness through local training among the Mru girls may have a significant influence on FP knowledge and the use of contraceptives in the Mru society.

\section{Acknowledgments}

We are thankful to the Mru leaders, interviewers, and, especially, Mru mothers for their valuable information, help, and cooperation during fieldwork. We also thank the Center for Sámi Studies, the Norwegian State Educational Loan Fund, and the Program of Indigenous Studies at the University of Tromsø for their financial support, which made this study possible as part of a master of philosophy thesis. We also thank Dr M Amirul Islam and Dr Mohammad Bellal Hossain for reading this manuscript and offering suggestions.

\section{Disclosure}

The authors report no conflicts of interest in this work. 


\section{References}

1. Kabir M, Moslehuddin M, Howlader AA. Husband-wife communication and status of women as determinants of contraceptive use in rural Bangladesh. Bangladesh Development Studies. 1988;16(1):85-97.

2. National Institute of Population Research and Training (NIPORT), Mitra and Associates, and Macro International. Bangladesh Demographic and Health Survey 2007. Dhaka and Calverton, MD: National Institute of Population Research and Training, Mitra and Associates, and Macro International; 2009.

3. National Institute of Population Research and Training (NIPORT), Mitra and Associates, and ORC Macro. Bangladesh Demographic and Health Survey 2004. Dhaka and Calverton, MD: National Institute of Population Research and Training, Mitra and Associates, and ORC Macro; 2005.

4. Ullah MS, Chakraborty N. Factors affecting the use of contraception in Bangladesh: a multivariate analysis. Asia Pac Popul J. 1993;8(3):19-30.

5. Piet-Pelon NJ. Male involvement in the Bangladesh family planning and reproductive health program. Proceedings of the Workshop on Male Involvement in Family Planning, August 7, 1997. Dhaka: Population Council; 1997.

6. Neaz A, Banu H. Male motivation programme for improving reproductive health. Proceedings of the Workshop on Male Involvement in Family Planning, August 7, 1997. Dhaka: Population Council; 1997.

7. Islam MA. Factors affecting current use of contraceptives: a multinomial logistic regression analysis. J Stat Stud. 2000;20:9-13.

8. Khan MA. Factors associated with oral contraceptive discontinuation in rural Bangladesh. Health Policy Plan. 2003;18(1):101-108.

9. Klitsch M. Half of Bangladeshi women who discontinue pill use attribute their decision to side effects. Int Fam Plan Perspect. 2002;28(1): 49-50.

10. Brauns C-D, Loffler LG. Mru: Hill People on the Border of Bangladesh. Berlin: Birkhauser; 1990.
11. Lewin TH. The Hill Tracts of Chittagong and the Dwellers Therein; With Comparative Vocabularies of the Hill Dialects. Calcutta: Bengal Printing; 1869.

12. Rafi M. Small Ethnic Groups of Bangladesh: A Mapping Exercise. Dhaka: Panjeree; 2006.

13. Mahmud Photographer. Ang Ing Mru Rung. Dhaka: Matri Productions; 2007.

14. Islam MR. Maternal Morbidity and Mortality Among Indigenous People in Bangladesh: A Study of the Mru Community. MPhill's thesis. Tromsø: University of Tromsø; 2010.

15. Islam MR, Odland JO. Determinants of antenatal and postnatal care visits among indigenous people in Bangladesh: a study of the Mru community. Rural and Remote Health. 2011;11:1672.

16. Agrawal PK. How much the indigenous women of Jharkhand, India are in disadvantageous condition: findings from India's National Family Health Survey [article on the Internet]. 2009. Available from: http:// paa2009.princeton.edu/download.aspx?submissionId=90455. Accessed February 9, 2012.

17. Arenas P, Azorero RM. Plants used as means of abortion, contraception, sterilization and fecundation by Paraguayan indigenous people. Econ Bot. 1977;31(3):302-306.

18. Ahmed SM. Health-care facilities, contraception and antenatal care services. In: Rafi M, Chowdhury AMR, editors. Counting the Hills: Assessing Development in Chittagong Hill Tracts. Dhaka: University Press; 2001.

19. Islam MA, Islam MR, Banowary B. Sex preference as a determinant of contraceptive use in matrilineal societies: a study on the Garo of Bangladesh. Eur J Contracept Reprod Health Care. 2009;14:(4)301-306.

20. World Health Organization. Unsafe Abortion: Global and Regional Estimates of the Incidence of Unsafe Abortion and Associated Mortality in 2003. 5th ed. Geneva: World Health Organization; 2007. Available from: http://whqlibdoc.who.int/publications/2007/9789241596121_eng. pdf. Accessed February 9, 2012.
Open Access Journal of Contraception

\section{Publish your work in this journal}

Open Access Journal of Contraception is an international, peerreviewed, open access, online journal, publishing original research, reports, reviews and commentaries on all areas of contraception. In addition to clinical research, demographics and health-related aspects, the journal welcomes new findings in animal and preclinical studies

\section{Dovepress}

relating to understanding the biological mechanisms and practical development of new contraceptive agents. The manuscript management system is completely online and includes a very quick and fair peer-review system. Visit http://www.dovepress.com/testimonials.php to read real quotes from published authors. 